\title{
Enhanced fibroblast growth factor 5 expression in stromal and exocrine elements of the pancreas in chronic pancreatitis
}

\author{
T Ishiwata, M Kornmann, H G Beger, M Korc
}

\begin{abstract}
Background-Fibroblast growth factor 5 (FGF-5) belongs to a group of mitogenic and angiogenic heparin binding growth factors but its potential role in chronic inflammatory conditions is not known. Aims-To compare FGF-5 expression in the normal pancreas and in the pancreas of patients with chronic pancreatitis $(\mathrm{CP})$ and to characterise FGF-5 expression and secretion in TAKA-1 cells, an immortalised Syrian hamster pancreatic duct cell line. Methods and results-Northern blotting revealed the presence of a $4.0 \mathrm{~kb}$ FGF-5 mRNA transcript in both normal and CP tissue samples. Densitometric analysis indicated that the transcript levels were increased by a factor of 1.44 in CP tissue samples compared with normal tissue samples $(p=0.039)$. By immunohistochemisty and in situ hybridisation, FGF-5 was faintly expressed in ductal and islet cells in the normal pancreas. In contrast, in CP tissue samples, there was abundant expression of FGF-5 in ductal, acinar, and islet cells, as well as in periductal fibroblasts. FGF-5 was also expressed in TAKA-1 cells as determined by Northern blotting. By immunoblotting of heparinsepharose precipitates, TAKA-1 cells were shown to secrete FGF-5 into the medium. Conclusion-Exocrine and stromal derived FGF-5 has the potential to participate in autocrine and paracrine pathways that may contribute to the pathobiology of chronic pancreatitis.

(Gut 1998;43:134-139)
\end{abstract}

Keywords: chronic pancreatitis; fibroblast growth factor; in situ hybridisation

Fibroblast growth factors (FGFs) are a group of homologous heparin binding polypeptides that are involved in various biological processes including stimulation of fibroblast proliferation and angiogenesis. ${ }^{1}$ The FGF family currently consists of 14 members: acidic FGF (aFGF or FGF-1), basic FGF (bFGF or FGF-2), FGF-3 (int-2), FGF-4 (hst/kFGF), FGF-5, FGF-6, keratinocyte growth factor (KGF or FGF-7), androgen induced growth factor (AIGF or FGF-8), glia activating factor (GAF or FGF9), FGF-10, ${ }^{2}$ and FGF-11-14 which are also known as FGF homologous factors $1-4 .^{34}$ The FGF-5 gene was originally discovered as a human oncogene which had acquired transforming potential, based on transfection stud- ies of NIH 3 T3 fibroblasts with human tumour DNA. ${ }^{5}$ FGF-5 encodes a glycosylated 267 amino acid protein that contains a hydrophobic $\mathrm{N}$-terminal sequence which allows its secretion from its cells of origin. ${ }^{6}$ It is overexpressed in a number of human malignancies, including hepatomas and carcinomas of the bladder, endometrium, and pancreas. ${ }^{6-8}$

Although FGF-5 is known to be expressed in inflammatory cells, ${ }^{8}$ the potential role of FGF-5 in chronic inflammatory conditions is not known. Therefore, in the present study, we characterised FGF-5 expression in chronic pancreatitis (CP), an inflammatory disease of the pancreas that may ultimately result in exocrine and endocrine dysfunction. ${ }^{9}$ Along with enlarged pancreatic ducts, pseudoductular hyperplasia, loss of parenchyma, and acinar cell degeneration there is significant replacement of the functional parenchyma by fibrosis in association with proliferation of fibroblasts and infiltration by inflammatory cells. ${ }^{10}$ We now report that FGF-5 expression is increased in CP where it is localised in ductal, acinar, and islet cells and in fibroblasts within the connective tissue. Furthermore, it is expressed and secreted by TAKA-1 cells, an immortalised hamster pancreatic duct cell line.

\section{Methods}

PATIENTS AND TISSUE SAMPLES

Normal human pancreatic tissue samples (from four men and two women; median age 24.5 years, range 22-44) were obtained through a donor programme. Chronic pancreatitis tissue samples were obtained from one female and eight male patients (median age 50 years, range 33-60) undergoing pancreatic surgery. ${ }^{11}$ Pancreatic adenocarcinoma tissue samples were obtained from 10 female and six male patients (median age 64 years, range 44-77) undergoing surgery for pancreatic cancer as recently described. ${ }^{8}$ On surgical removal samples were either immediately frozen in liquid nitrogen and stored at $-80^{\circ} \mathrm{C}$ until RNA extraction or fixed in Bouin's solution for 18-20 hours and embedded in paraffin wax for histological analysis. Studies involving human tissue were approved by the Ethics Committee of the University of Ulm, Germany and the Human Subjects Committee of the University of California, Irvine, California, USA.

\section{CELL CULTURE}

TAKA-1 immortalised Syrian hamster pancreatic duct cells were a gift from Dr Parviz Pour, University of Nebraska, Omaha, Nebraska,
Accepted for publication 19 January 1998 
USA, and were grown in Dulbecco's modified Eagle's/F 12 medium at $37^{\circ} \mathrm{C}$ in humidified air with $5 \% \mathrm{CO}_{2}$. Medium contained $100 \mathrm{U} / \mathrm{ml}$ penicillin, $100 \mu \mathrm{g} / \mathrm{ml}$ streptomycin, and $5 \%$ foetal bovine serum.

\section{NORTHERN BLOT ANALYSIS}

Northern blotting was carried out as previously described. ${ }^{12}$ Total RNA was extracted, size fractionated, electrotransferred to nylon membranes, and hybridised under high stringency conditions with a 306 bp human FGF-5 cDNA fragment. ${ }^{8}$ A $190 \mathrm{bp}$ mouse $7 \mathrm{~S}$ cDNA was used as loading control. ${ }^{12} \mathrm{cDNAs}$ were labelled with $\left[\alpha{ }^{32} \mathrm{P}\right] \mathrm{dCTP}(3000 \mathrm{Ci} / \mathrm{mmol})$ by random priming prior to hybridisation. The resulting autoradiographs were scanned and the ratio of the optical densities of the RNA levels (FGF-5:7S) was calculated for each sample. ${ }^{8}$

\section{IMMUNOHISTOCHEMISTRY}

Immunohistochemistry was carried out as previously described. ${ }^{8}$ Briefly, $4 \mu \mathrm{m}$ paraffin wax embedded tissue sections were immunostained using the streptavidin-peroxidase technique (Kirkegaard \& Perry Laboratories Inc., Gaithersburg, Maryland, USA). After deparaffinisation and blocking of endogenous peroxidase activity, sections were incubated for 15 minutes at $23^{\circ} \mathrm{C}$ with $10 \%$ normal rabbit serum and then incubated with highly specific goat polyclonal antihuman FGF-5 antibodies (1/ 100 in phosphate buffered saline (PBS) containing 1\% BSA; Santa Cruz Biotechnology, Santa Cruz, California, USA) at $4^{\circ} \mathrm{C}$ for 16 hours. ${ }^{8}$ Bound antibody was detected with a biotinylated rabbit antigoat IgG secondary antibody and streptavidin-peroxidase complex (Kirkegaard \& Perry), using diaminobenzidine tetrahydrochloride (DAB) as the substrate. For insulin staining guinea pig polyclonal antiporcine insulin antibodies (1/1000 in PBS containing 1\% BSA; Dako Corp., Carpinteria, California, USA), cross reactive with human insulin, and biotinylated goat antiguinea pig IgG secondary antibodies (Kirkegaard \& Perry) were used after incubation with $10 \%$ normal goat serum. Sections were counterstained with Mayer's haematoxylin. Omission of primary antibodies or incubation in the presence of non-immunised goat serum in-
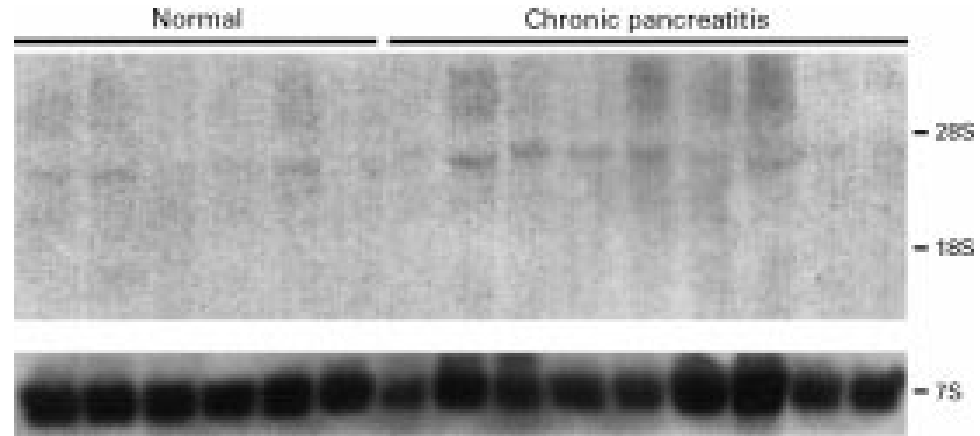

Figure 1 Expression of FGF-5 $m R N A$ in the normal human pancreas and in chronic pancreatitis. Northern blotting of total RNA (20 $\mu$ g/lane) was carried out using a $306 \mathrm{bp}$ human FGF-5 cDNA fragment, randomly labelled with $\left[\mathrm{a}^{32} \mathrm{P}\right] \mathrm{dCTP}(750000 \mathrm{cpm} / \mathrm{ml}$; 14 day exposure). A mouse $7 S c D N A$ probe, cross reactive with human $7 S$, was used as a loading control (40 $000 \mathrm{cpm} / \mathrm{ml}$; six hour exposure). rRNA markers are shown on the right. stead of primary antibodies did not yield any immunoreactivity.

IN SITU HYBRIDISATION

Tissue sections were placed on 3-aminopropylmethoxysilane coated slides, deparaffinised, and incubated sequentially at $23^{\circ} \mathrm{C}$ for 20 minutes with $0.2 \mathrm{~N} \mathrm{HCl}$ and for 15 minutes with $20 \mu \mathrm{g} / \mathrm{ml}$ proteinase $\mathrm{K}$ at $37^{\circ} \mathrm{C} .{ }^{8}$ The sections were then postfixed for five minutes in PBS containing 4\% paraformaldehyde, and quenched twice with glycine $(2 \mathrm{mg} / \mathrm{ml})$ in PBS. They were then incubated in $50 \%$ (vol/vol) formamide/ $2 \times$ saline sodium citrate (SSC) for one hour. The hybridisation buffer contained $0.6 \mathrm{M} \mathrm{NaCl}, 1 \mathrm{mM}$ EDTA, $10 \mathrm{mM}$ Tris- $\mathrm{HCl}$ ( $\mathrm{pH} 7.5$ ), $0.25 \%$ sodium dodecyl sulphate (SDS), $200 \mu \mathrm{g} / \mathrm{ml}$ yeast tRNA, $1 \times$ Denhart's solution, $10 \%$ dextran sulphate, $40 \%$ formamide, and $50 \mathrm{ng} / \mathrm{ml}$ digoxigenin labelled FGF-5 riboprobe. Hybridisation was initiated by applying $100 \mu \mathrm{l}$ of the hybridisation buffer to each section, followed by incubation in a moist chamber for 16 hours at $42^{\circ} \mathrm{C}$. For immunological detection, the Genius 3 non-radioactive nucleic acid detection kit was used (Boehringer, Mannheim, Germany). The sections were then washed sequentially with $50 \%$ formamide $/ 2 \times \mathrm{SSC}$ for 30 minutes at $50^{\circ} \mathrm{C}, 2 \times$ SSC for 20 minutes at $50^{\circ} \mathrm{C}, 0.2 \times$ SSC for 20 minutes at $50^{\circ} \mathrm{C}$, and $0.1 \times$ SSC for 30 minutes at $50^{\circ} \mathrm{C}$. The sections were washed briefly with buffer 1 solution $(100 \mathrm{mM}$ Tris- $\mathrm{HCl}$ and 150 $\mathrm{mM} \mathrm{NaCl}, \mathrm{pH} 7.5)$ and incubated with $1 \%$ (wt/vol) blocking reagents in buffer 1 solution for 60 minutes at $23^{\circ} \mathrm{C}$. After washing briefly with buffer 1 , the sections were incubated for 30 minutes at $23^{\circ} \mathrm{C}$ with a $1 / 2000$ dilution of alkaline phosphatase conjugated polyclonal sheep antidigoxigenin $\mathrm{Fab}$ fragment containing $0.2 \%$ Tween 20 . The sections were then washed twice for 15 minutes at $23^{\circ} \mathrm{C}$ with buffer 1 solution containing $0.2 \%$ Tween 20 and equilibrated with buffer $3(100 \mathrm{mM}$ Tris- $\mathrm{HCl}, 100 \mathrm{mM} \mathrm{NaCl}, 50 \mathrm{mM} \mathrm{MgCl}, \mathrm{pH}$ 9.5) for two minutes. The sections were then incubated with colour solution containing nitroblue tetrazolium and $\mathrm{X}$ phosphate in a dark box for two to three hours. After the reaction was stopped with Tris-EDTA (TE) buffer, the sections were mounted in aqueous mounting medium.

\section{PURIFICATION AND IMMUNOBLOTTING OF FGF- 5} PROTEIN

FGF-5 protein purification was carried out as previously described. ${ }^{78}$ TAKA- 1 cells were grown in complete medium containing 5\% FBS to $90 \%$ confluency in T75 flasks. After washing twice with Hank's buffered saline solution, cells were incubated for 48 hours in $10 \mathrm{ml}$ of serum free medium containing 50 $\mu \mathrm{g} / \mathrm{ml}$ aprotinin, $10 \mu \mathrm{g} / \mathrm{ml}$ leupeptin, $10 \mu \mathrm{g} / \mathrm{ml}$ pepstatin $\mathrm{A}$, and $10 \mu \mathrm{g} / \mathrm{ml}$ benzamidine. The conditioned serum free medium from five flasks was collected $(50 \mathrm{ml})$ and incubated at $4^{\circ} \mathrm{C}$ overnight after adjusting the $\mathrm{pH}$ to 7.4 and adding a $50 \mu \mathrm{l}$ slurry of heparin sepharose. Serum free medium $(50 \mathrm{ml})$ with inhibitors served as negative control, serum free medium 


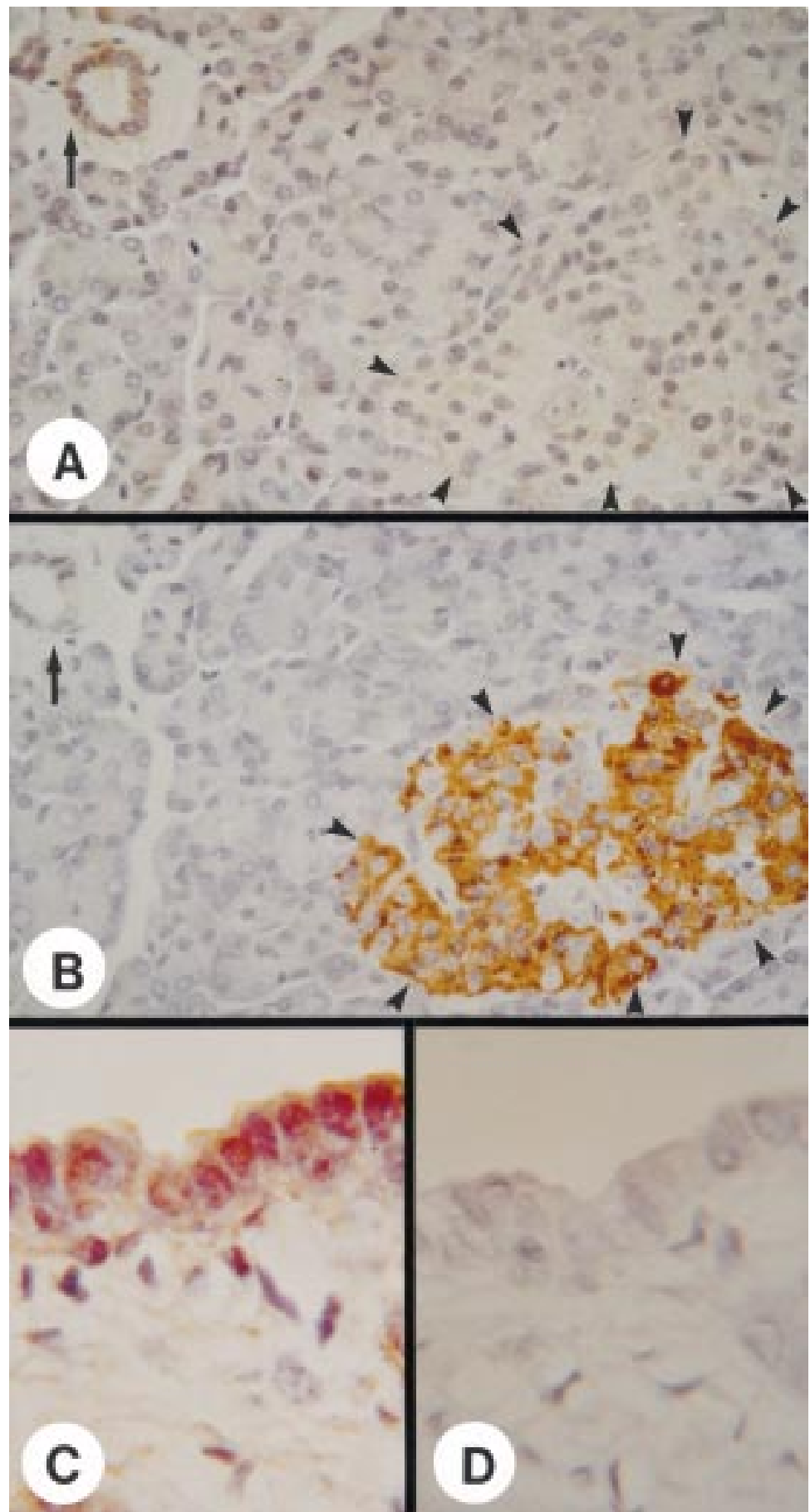

Figure 2 Immunohistochemistry of FGF-5 in the normal pancreas. (A) Faint FGF-5 immunoreactivity was present in many ductal cells forming the small ducts (arrow) and, to a lesser extent, in islet cells (arrowheads). (B) Localisation of endocrine islets (arrowheads) in a serial section using an antiporcine insulin antibody, cross reactive with human insulin. The ductal cells forming the small ducts (solid arrow) were devoid of insulin

immunoreativity. (C) Moderate FGF-5 immunoreactivity was present in the ductal cells of larger ducts and in the fibroblasts within the surrounding stroma. (D) Negative control without primary antibody did not show any positive immunoreactivity. Original magnification: $\times 500(A, B) ; \times 1250(C, D)$.

$(50 \mathrm{ml})$ with inhibitors and $500 \mathrm{ng}$ recombinant FGF-5 (Sigma Chemical Co., St Louis, Missouri,USA) as positive control. The beds were washed three times with $0.45 \mathrm{M}$ $\mathrm{NaCl} / 20 \mathrm{mM}$ Tris- $\mathrm{HCl}(\mathrm{pH}$ 7.4) and subjected to $12 \%$ SDS polyacrylamide gel electrophoresis and western blotting with the highly specific FGF-5 antibody used for immunostaining. ${ }^{8}$
STATISTICS

Data are expressed as median and range. The Mann-Whitney rank sum test (two sided) was used to investigate the differences in median mRNA expression levels. A $p$ value of less than 0.05 was taken as the level of significance.

\section{Results}

EXPRESSION OF FGF- 5 mRNA IN THE NORMAL

PANCREAS AND IN CHRONIC PANCREATITIS

Northern blotting of total RNA isolated from six normal and nine CP tissue samples revealed the presence of the reported $4.0 \mathrm{~kb}$ and $1.6 \mathrm{~kb}$ mRNA transcripts. Even after 14 days' exposure of the autoradiographs, relatively low levels of the $4.0 \mathrm{~kb}$ transcript were detectable in three of six normal pancreatic tissue samples (fig 1). In contrast, in five of nine CP tissue samples the $4.0 \mathrm{~kb}$ transcript was expressed at relatively high levels. Furthermore, in four of nine CP samples the $1.6 \mathrm{~kb}$ transcript was evident on the original autoradiograph (fig 1). In three of the CP tissue samples a larger band (approximately $6 \mathrm{~kb}$ ) of unknown significance was also visible. This mRNA transcript, which may represent a splice variant or a homologous RNA species, was also previously observed in some pancreatic cancer tissue samples. ${ }^{8}$ Densitometric analysis of the northern blots indicated that the median value of the $4.0 \mathrm{~kb}$ FGF-5 transcript levels was increased by a factor of 1.44 in CP by comparison with the corresponding level in normal pancreatic tissue samples $(p=0.039)$.

\section{IMMUNOHISTOCHEMISTRY OF FGF-5 IN}

PANCREATIC TISSUE SAMPLES

In the normal pancreas, immunostaining with a highly specific antihuman FGF-5 antibody revealed the presence of faint to moderate FGF-5 immunoreactivity in the cytoplasm of ductal cells (fig $2 \mathrm{~A}, \mathrm{C}$ ), vascular smooth muscle cells (not shown), and periductal fibroblasts around the large ducts (fig 2C). Islet cells exhibited faint and diffuse FGF-5 immunoreactivity (fig 2A, outlined by arrowheads), whereas acinar cells were devoid of FGF-5 immunoreactivity. As expected, many of the islet cells were strongly positive for insulin, whereas the ductal and acinar cells were devoid of insulin immunoreactivity (fig $2 \mathrm{~B}$ ). In the CP tissue samples, moderate to strong FGF-5 immunoreactivity was observed in foci of proliferative ductal cells (fig 3A, outlined by solid arrowheads) that are characteristic of this disorder. Moderate to strong FGF-5 immunoreactivity was also evident in acinar cells (fig $3 \mathrm{~A}$, outlined by open arrowheads), islet cells (not shown), and in fibroblasts within the connective tissue (fig 3A, solid arrow). Macrophages infiltrating the fibrotic tissues were also strongly positive for FGF-5 immunoreactivity (not shown).

We have previously reported that FGF-5 mRNA levels are elevated in pancreatic cancers. ${ }^{8}$ The pancreatic parenchyma immediately adjacent to the cancer cell areas often exhibits so called CP-like alterations consisting of regions of ductal cell proliferation, acinar cell degeneration, and increased levels of colla- 


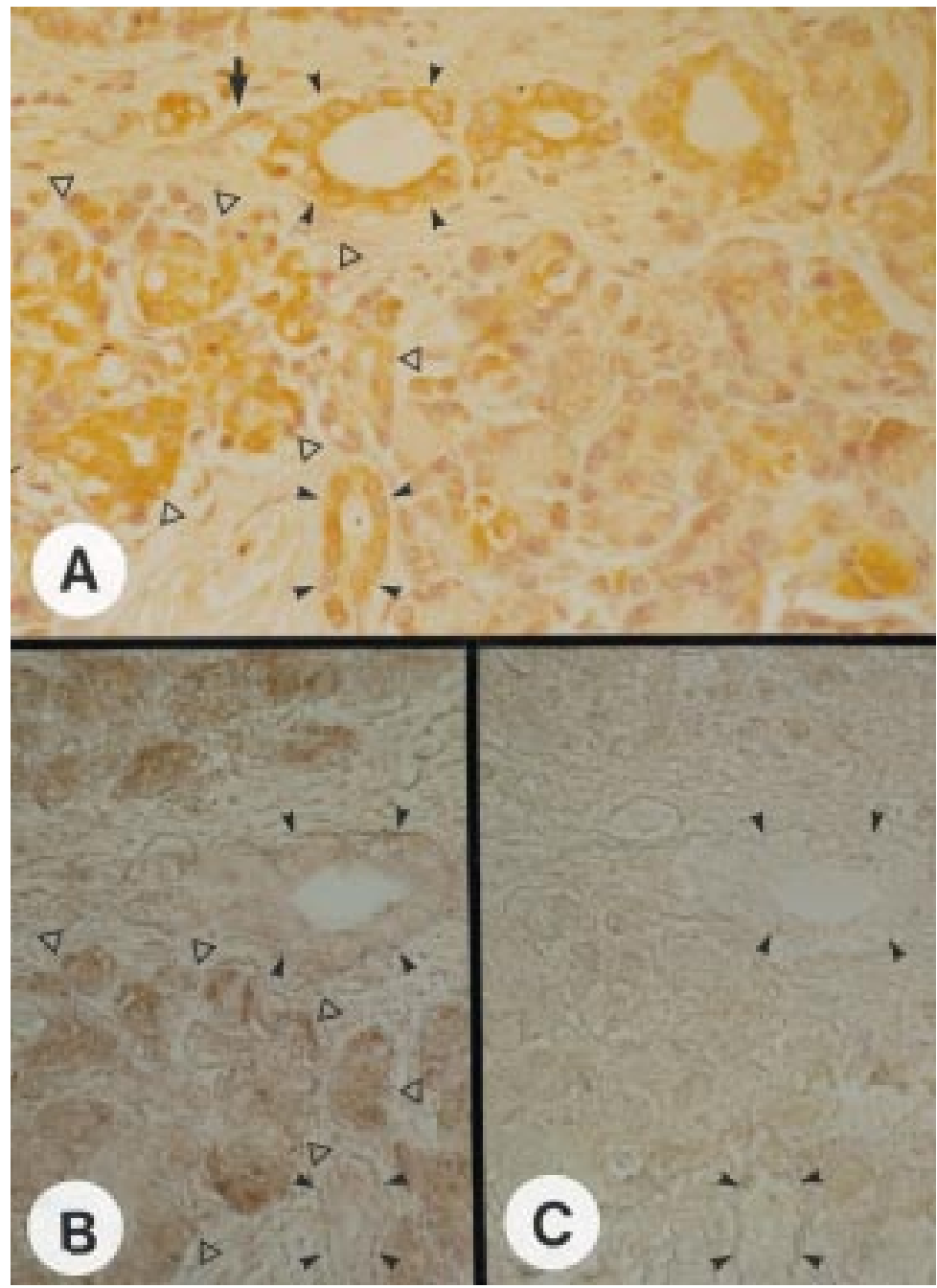

Figure 3 Localisation and expression of FGF-5 in chronic pancreatitis. (A) Immunostaining showed moderate to strong FGF-5 immunoreactivity in the cytoplasm of ductal cells (solid arrowheads), acinar cells (open arrowheads), and fibroblasts (arrow). (B) In situ hybridisation analysis of serial sections revealed a mild to moderate FGF-5 $m R N A$ signal in ductal cells (solid arrowheads) and fibroblasts, and a moderate to strong $F G F-5$ mRNA signal in acinar cells (open arrowheads). A sense FGF-5 probe (C) did not show any signal. Original magnification: $\times 500$.

gen, fibroblasts, and stromal elements. Therefore, we investigated whether these CP-like regions exhibited any FGF-5 immunoreactivity. Increased FGF-5 immunoreactivity was observed in the foci of proliferating ductal cells adjacent to the cancer (fig 4A). Stromal fibroblasts (fig 4A) and macrophages (fig 4A, solid arrowheads) in these $\mathrm{CP}$-like regions also exhibited moderate to strong FGF-5 immunoreactivity. To exclude the possibility of nonspecific staining by intrinsic peroxidase that may be abundant in inflammatory cells, we also used alkaline phosphatase labelled streptavidin and new fuchsin instead of the peroxidase labelled streptavidin and DAB system. Similar results for FGF-5 staining were obtained by both methods (fig 4B).

IN SITU HYBRIDISATION OF FGF-5 IN PANCREATIC TISSUE SAMPLES

In order to determine the site of synthesis of FGF-5, in situ hybridisation of serial sections was carried out. In the normal pancreas, only a faint FGF-5 mRNA signal was present in ductal and islet cells (not shown). In the CP tissue samples, a faint to moderate FGF-5 mRNA signal was present in ductal cells (fig $3 \mathrm{~B}$, outlined by solid arrowheads), islet cells (not shown), and fibroblasts in fibrotic tissues (fig 3B). A moderate to strong FGF-5 mRNA signal was observed in the partially atrophic acinar cells adjacent to the foci of proliferative ductal cells and fibrotic tissues (fig 3B, outlined by open arrowheads) and also in infiltrating macrophages (not shown). The CP-like regions of the cancer tissue samples displayed a similar pattern of FGF- 5 mRNA expression in acinar and islet cells, fibroblasts, and infiltrating macrophages (fig 4C). However, in comparison with the CP tissue samples, the FGF-5 mRNA signal was stronger in ductal cells and observed in more fibroblasts and macrophages (fig 4C, arrowheads). In situ hybridisation with a sense FGF-5 probe did not produce any specific signal in the normal pancreas (not shown), in CP (fig 3C), and in the CP-like regions of pancreatic cancers (fig 4D).

EXPRESSION AND SECRETION OF FGF-5 IN TAKA-1 PANCREATIC DUCT CELLS

The FGF-5 gene encodes a glycosylated protein that includes a leader sequence for rapid secretion. ${ }^{6}$ It is not known, however, whether relatively well differentiated exocrine cells can secrete FGF-5. Therefore, we next sought to determine whether FGF-5 was expressed and secreted in the TAKA-1 immortalised Syrian hamster pancreatic duct cell line. Northern blotting of total RNA prepared from TAKA-1 cells revealed the presence of high levels of a $1.6 \mathrm{~kb}$ FGF-5 mRNA transcript and lower levels of a $3.1 \mathrm{~kb}$ transcript (fig 5A). RNA from COLO-357 cells, known to express a 4.0 kb FGF-5 transcript, ${ }^{8}$ was used as positive control. To show that TAKA-1 cells secrete FGF-5, western blotting of heparin-sepharose precipitates from serum free conditioned medium of TAKA-1 cells was carried out, revealing bands of $29,31,31.5$, and $33 \mathrm{kDa}$ (fig 5B), corresponding to secreted FGF- 5 proteins. ${ }^{7}$ In contrast, recombinant FGF-5 migrated as a 29 $\mathrm{kDa}$ protein (fig $5 \mathrm{~B}$ ).

\section{Discussion}

FGF-5 is a heparin binding glycoprotein with mitogenic activity towards fibroblasts and endothelial cells. ${ }^{67}$ Initially, its expression was believed to be limited to certain tissues during development. ${ }^{13}$ Subsequently, it was also detected in fibroblasts, ${ }^{14}$ skeletal muscle cells, ${ }^{15}$ and in adult myotropic ${ }^{16}$ and neurotropic tissues. ${ }^{13}{ }^{17}$ Recent studies, however, have indicated that FGF-5 is expressed in hepatomas, bladder and pancreatic carcinoma cell lines, ${ }^{681819}$ cultured teratocarcinoma cell aggregates, ${ }^{20}$ and human pancreatic cancers. ${ }^{8}$ FGF-5 was also shown to be mitogenic towards human pancreatic cancer cells. ${ }^{8}$ Together, these observations suggest that FGF-5 might be involved in the carcinogenic process in certain types of malignancies.

In the present study we showed by immunostaining and in situ hybridisation of serial sections that FGF- 5 protein and mRNA are 


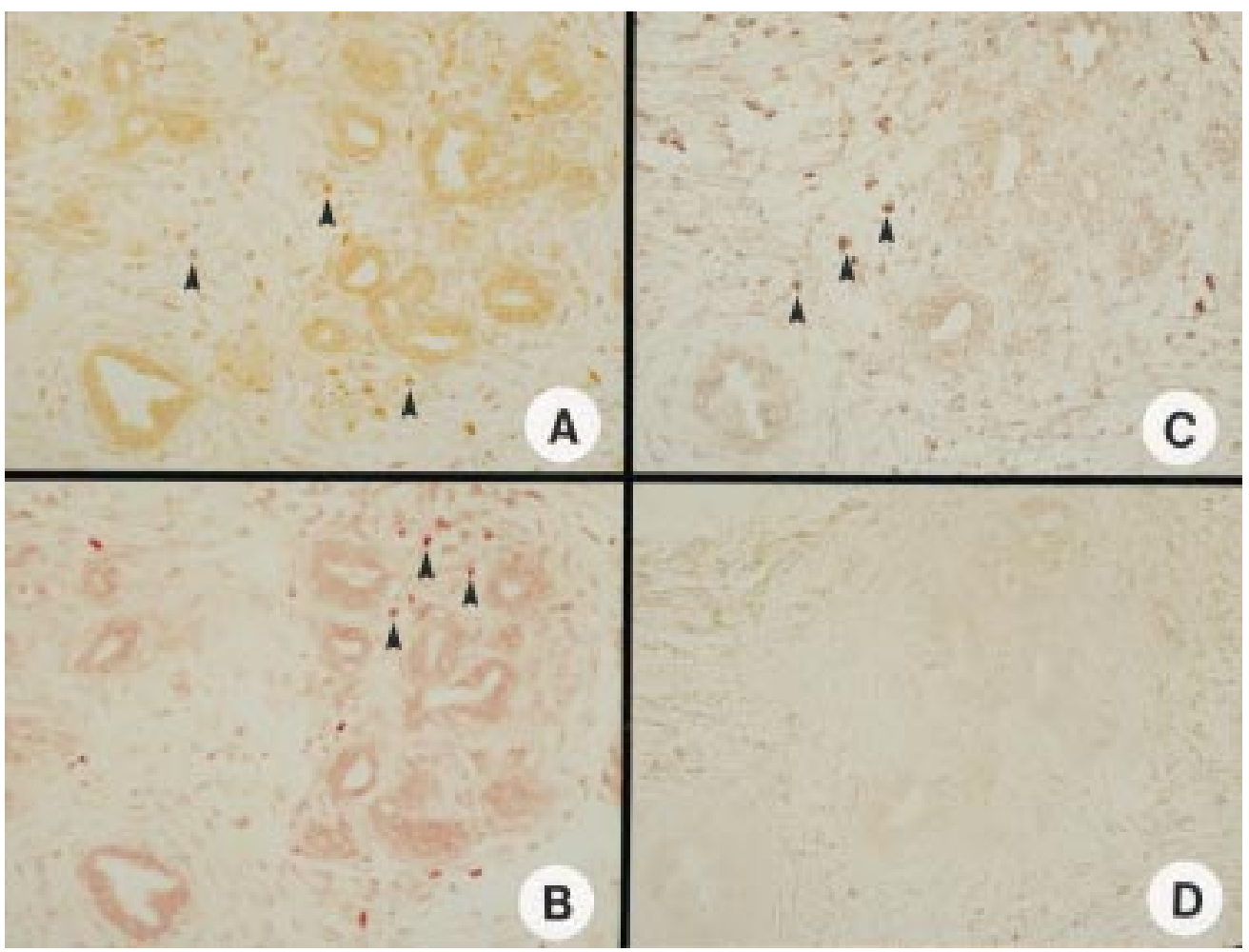

Figure 4 Localisation and expression of FGF-5 in the chronic pancreatitis-like regions adjacent to the cancer cells in the pancreatic cancer samples. (A) Immunostaining showed moderate to strong FGF-5 immunoreactivity in the cytoplasm of proliferating ductal cells, fibroblasts, and infiltrating macrophages (arrowheads), but not in the abundant connective tissue stroma. (B) Immunostaining of serial sections with alkaline phosphatase labelled streptavidin and new fuchsin also showed moderate to strong FGF-5 immunoreactivity in proliferating ductal cells, fibroblasts, and infiltrating macrophages (arrowheads). (C) In situ hybridisation analysis of serial sections revealed a moderate FGF-5 mRNA signal in proliferating ductal cells and fibroblasts, and a strong FGF-5 mRNA signal in the macrophages (arrowheads). In contrast, a sense $F G F-5$ probe (D) did not show any signal. Original magnification: $\times 250$.

present in several different cell types in the pancreas in CP, indicating that FGF-5 was produced and secreted in this inflammatory condition. On immunostaining, increased levels of FGF-5 protein were present in ductal and acinar cells of CP tissues in comparison with the normal human pancreas. Furthermore, a moderate to strong FGF-5 mRNA signal was observed by in situ hybridisation in the acinar cells in CP, indicating that the observed immunoreactivity in this cell type was due to
A

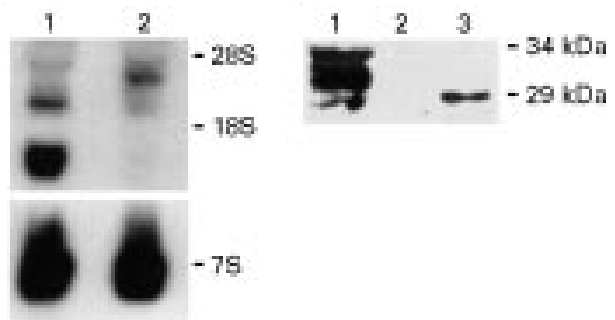

Figure 5 FGF-5 $m R N A$ expression and FGF-5 protein secretion in TAKA-1 Syrian hamster pancreatic duct cells.

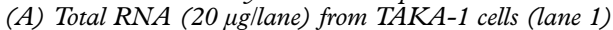
and COLO-357 human pancreatic cancer cells (lane 2, positive control) was used for northern blot analysis with a human FGF-5 cDNA probe $(750000 \mathrm{cpm} / \mathrm{ml}$, four day exposure). A mouse $7 S c D N A$ probe was used as a loading control (40 $000 \mathrm{cpm} / \mathrm{ml}$; eight hour exposure). rRNA markers are shown on the right. (B) Western blotting of the heparin-sepharose precipitates from two day conditioned serum free medium of TAKA-1 cells (lane 1), serum free medium (lane2), and serum free medium with $500 \mathrm{ng}$ FGF-5 (lane 3) was carried out with a specific antihuman FGF-5 antibody $(0.8 \mathrm{\mu g} / \mathrm{ml}, 45$ minute exposure). Molecular weight markers are shown on the right. enhanced FGF- 5 synthesis. In contrast, a faint to moderate FGF-5 mRNA signal was seen in the ductal cells. In view of the strong immunostaining observed in this cell type these data suggest that the ductal cells in CP exhibit either an attenuated capacity to degrade FGF- 5 or an enhanced capacity to internalise FGF- 5 released by the adjacent acinar cells and fibroblasts. Interestingly, the foci of proliferating ductal cells in the CP-like regions of pancreatic cancer displayed both a strong FGF-5 immunostaining signal and a strong in situ hybridisation signal, indicating that these cells have a greater capacity to synthesise FGF- 5 by comparison with the ductal cells in CP. This possibility is strengthened by the observation that the well differentiated TAKA-1 Syrian hamster pancreatic duct cell line expressed and secreted large quantities of FGF-5.

The reason for the detection of four protein species in TAKA-1 cells is not known. One possibility for this heterogeneity is that FGF-5 moieties are generated by differential glycosylation, as previously reported in cultured fibroblasts. ${ }^{7}$ Alternatively, it is possible that different FGF-5 species are synthesised from different FGF-5 mRNA moieties. In support of this hypothesis we observed two FGF- 5 mRNA transcripts in TAKA-1 cells. Although the biological functions of different secreted FGF-5 proteins have yet to be determined, our observations suggest that FGF- 5 can contribute to 
autocrine and paracrine interactions in the pancreas of patients with CP. To our knowledge this is the first report to implicate FGF-5 in the pathogenesis of a chronic inflammatory disorder.

The molecular mechanisms underlying the increased expression of FGF-5 in CP and in the CP-like cancer lesions are not known. It is possible that FGF-5 synthesis is induced in some of these cell types as a consequence of aberrant paracrine loops driven by the excessive production of other growth factors and cytokines. In support of this hypothesis, FGF-5 mRNA expression in human fibroblasts is known to be induced by transforming growth factor $\alpha$ and epidermal growth factor, ${ }^{14}$ whose expression is increased in both CP and pancreatic cancer. ${ }^{121}$

Acidic FGF and basic FGF are also overexpressed in CP. Both growth factors localise in atrophic acinar cells and in regions of pseudoductular metaplasia, but not in the fibroblasts. ${ }^{22}$ Furthermore, in contrast to FGF-5, acidic FGF and basic FGF are not efficiently secreted. ${ }^{1}$ Our observations thus raise the possibility that acidic and basic FGF may function principally in an autocrine manner in CP. In contrast, the relative abundance of FGF-5 in the exocrine components as well as in stromal fibroblasts in CP indicates that FGF-5 may participate in both autocrine and paracrine regulatory pathways in CP. Together, these observations suggest that FGFs may contribute through a variety of mechanisms to promote fibrotic and inflammatory activity in $\mathrm{CP}$, raising the possibility that modalities aimed at abrogating FGF dependent pathways may ultimately have a therapeutic role in this chronic disorder.

This work was supported by Public Health Service Grant CA-40162 awarded by the NIH to M Korc. M Kornmann was the recipient of postdoctoral fellowship award 1716/1-2 from the Deutsche Forschungsgemeinschaft. We thank $\mathrm{Dr} F$ Gansauge (University of Ulm) for providing some of the tissue specimens and Dr Parviz Pour for the TAKA-1 cells.

1 Burgess WH, Winkles JA. The fibroblast growth factor family: multifunctional regulators of cell proliferation. In Pusztai L, Lewis CE, Yap E, eds. Proliferation in cancer, regulatory mechanisms of neoplastic cell growth. New York: Oxford University Press, 1996:154-217.

2 Emoto H, Tagashira S, Mattei M-G, et al. Structure and expression of human fibroblast growth factor-10. F Biol Chem 1997;272:23191-4.
3 Smallwood PM, Munoz-Sanjuan I, Tong P, et al. Fibroblast growth factor (FGF) homologous factors: new members of the FGF family implicated in nervous system development. Proc Natl Acad Sci USA 1996;93:9850-7.

4 Coulier F, Pontarotti P, Roubin R, et al. Of worms and men: an evolutionary perspective on the fibroblast growth factor (FGF) and FGF receptor families. $\mathcal{F ~ M o l ~ E v o l ~ 1 9 9 7 ; 4 : 4 3 - ~}$ 57.

5 Zhan X, Culpepper A, Reddy M, et al. Human oncogenes detected by a defined medium culture assay. Oncogene 1987;1:369-76.

6 Zhan X, Bates B, Hu X, Goldfarb M. The human FGF-5 oncogene encodes a novel protein related to fibroblast growth factors. Mol Cell Biol 1988;8:3487-95.

7 Bates B, Hardin J, Zhan X, et al. Biosynthesis of human fibroblast growth factor-5. Mol Cell Biol 1991;11:1840-5.

8 Kornmann M, Ishiwata T, Beger HG, et al. Fibroblast growth factor- 5 stimulates mitogenic signaling and is overexpressed in human pancreatic cancer: evidence for autocrine and paracrine actions. Oncogene 1997;15:141724.

9 Holt S. Chronic pancreatitis. Southern Med f 1993;86:201-

10 Oertel JE, Heffess CS, Oertel YC. Pancreas. In: Sternberg SS, ed. Diagnostic surgical pathology. New York: Raven Press, 1989:1057-93.

11 Beger HG, Büchler M. Duodenum preserving resection of the head of the pancreas in chronic pancreatitis with inflammatory mass in the head. World F Surg 1990;14:83-7.

12 Korc M, Chandrasekar B, Yamanaka Y, et al. Overexpression of the epidermal growth factor receptor in human pancreatic cancer is associated with concomitant increase in the levels of epidermal growth factor and transforming growth factor alpha. 7 Clin Invest 1992;90:1352-60.

13 Goldfarb M, Bates B, Drucker B, et al. Expression and possible functions of the FGF-5 gene. Ann NY Acad Sci 1991; 638:38-52.

14 Werner S, Roth WK, Bates B, et al. Fibroblast growth factor-5 proto-oncogene is expressed in normal human fibroblasts and induced by serum growth factors. Oncogene 1991;6:2137-44.

15 Hannon K, Kudla AJ, McAvoy MJ, et al. Differentially expressed fibroblast growth factors regulate skeletal muscle development through autocrine and paracrine mechanisms. F Cell Biol 1996;132:1151-9.

16 Hughes RA, Sendtner M, Goldfarb M, et al. Evidence that fibroblast gorwth factor 5 is a major muscle-derived survival factor for cultured spinal motoneurons. Neuron 1993;10:369-77.

17 Kitaoka T, Aotaki-Keen AE, Hjelmeland LM. Distribution of FGF-5 in the rhesus macaque retina. Invest Ophthal Vis Sci 1994;35:3189-98.

18 Altorki N, Schwartz GK, Blundell M, et al. Characterization of cell lines established from human gastric-esophageal adenocarcinomas. Biologic phenotype and invasion potential. Cancer 1993;72:649-57.

19 Yoshimura $\mathrm{K}$, Eto $\mathrm{H}$, Miyake $\mathrm{H}$, et al. Messenger ribonucleic acids for fibroblast growth factors and their receptor in bladder and renal cell carcinoma cell lines. Cancer Lett 1996;103:91-7.

20 Herbert JM, Boyle M, Martin GR. mRNA localization studies suggest that murine FGF-5 plays a role in gastrulation. Development 1991;112:407-15.

21 Friess H, Yamanaka Y, Büchler M, et al. Morphological and molecular evidence for an epidermal growth factor receptor autocrine loop in chronic pancreatitis. Gut 1993;34:S19

22 Friess H, Yamanaka Y, Büchler $M$, et al. Increased expression of acidic and basic fibroblast growth factors in chronic pancreatitis. Am f Pathol 1994;114:117-28. 